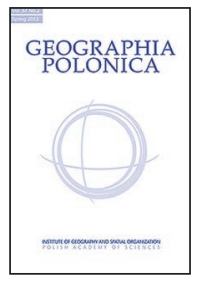

\title{
OWNERSHIP TRANSFORMATION IN EAST-CENTRAL EUROPE IN THE PRE EU-ACCESSION PERIOD. INTER-FIRM TIES AND CONTROL FUNCTIONS: THE CASE OF POLAND
}

\author{
Przemysław Śleszyński (D) - Ewa Korcelli-Olejniczak (D) \\ Institute of Geography and Spatial Organization \\ Polish Academy of Science \\ Twarda 51/55, 00-818 Warsaw: Poland \\ e-mails: psleszyn@twarda.pan.pl (corresponding author) • eko@twarda.pan.pl
}

\begin{abstract}
The Article focuses on the first period of political and socio-economic transformation in Poland (1989-2004) and describes the change in capital ownership links during the transition from a centrally planned to a free market economy. It constitutes an important research issue in the context of understanding the economic transformation in East-Central Europe, in particular the mechanisms of flow of foreign capital into certain areas in space. The processes have brought about a new organization of linkages between these realms, especially between large metropolitan areas. The spatial pattern of capital ownership links of large enterprises in Poland (1242 firms) is analyzed against the hierarchical structure of the national urban system. It is shown that in the process of inflow of foreign investments, the city of Warsaw has assumed a nodal position in the network of transnational and inward capital linkages, Spatial inter-firm ownership relations, as documented in the study are discussed and generalized in the form of a two-layer core-periphery model. The empirical results demonstrate how the foreign investments have contributed to the metropolization phenomena by fostering the position of the capital city as well as of other large urban centres.
\end{abstract}

\section{Key words}

post-socialist transformation $\cdot$ EU-accession $\bullet$ inter-firm links $\bullet$ ownership $\bullet$ city networks $\bullet$ decision-control functions

\section{Introduction}

In geographical terms, the transition from a centrally controlled to a free market economy after 1989 in the countries of Central and Eastern Europe consisted, among other things, in relocating decision-control functions in relation to the urban system. The significance of this research issue lies in the understanding of the economic changes in East-Central Europe, in particular the mechanisms regulating the direction of capital flows. The transformation has brought about a new organization of linkages between spatial 
realms, especially large metropolitan areas and it constitutes a key foundation for more recent change which took place after the EU accession in 2004.

As pointed out by Ben Derudder, Michael Timberlake and Frank Witlox (2010: 1836), and following Derudder (2006), two streams of enquiry may be identified within the growing body of literature on inter-city relations, in particular the work pertaining to transnational urban networks - the streams that are labeled the corporate organization approach and the infrastructure approach. Whereas the former focuses on transnational location strategies pursued by firms (Beaverstock et al.,2000; Taylor, 2001, 2004; Taylor \& Aranya, 2008; Derudder et al., 2010), the latter looks at broadly defined communication means and patterns which refer not only to technical and economic, but also social and political linkages (Tornqvist, 1984; Castells, 2000; Derudder \& Witlox, 2005; Matthiessen et al., 2010). In the present paper, some aspects of these two approaches are reflected upon in the way that firms' ownership links are mapped and their role evaluated against the urban system's hierarchy which comprises the main framework of spatial organization of human - social and economic activity at the national level (Warneryd, 1968; Berry, 1973; Pred, 1975; Bourne et al., 1984; Pumain, 2000; Taylor, 2009; Taylor et al., 2010).

In the paper we focus on the development of inter-firm capital linkages across Poland's settlement hierarchy, as well as on external, i.e. international ownership relations of firms located in Poland. As noted by Celine Rozenblat (2010), empirical studies on firm networks between cities (such as the work by Cohen, 1981; Rozenblat \& Pumain, 1993; Taylor, 2004) deal primarily with intra-firm relations, as data on inter-firm links are rarely available. Yet, it is the latter that exert a heavy impact upon the overall firms' strategies as well (see: Dicken, 1976, 2000). Since our main interest concerns the role of economic control (i.e. decision power) in inter-city relations, we look at the location of firms' headquarters and at the patterns of their outward ownership ties. While analyzing the ownership-based firms' connectivity in reference to their location within ex ante defined urban hierarchy (Borchert, 1978; Wheeler \& Brown, 1985; Tonts \& Taylor, 1010), we provide data and offer some generalizations in an attempt to contribute yet another aspect to the study of cities that are linked through, and are at the same time also perceived as networks (Castells, 2010; Pflieger \& Rosenblat, 2010). In doing this, the focus is put on the role of Warsaw as the location of economic control functions of national range (Śleszyński, 2015), but first of all as a connector (Allen 2010) of capital networks operating at different levels of spatial scale. It is also aimed at identifying the role played by large enterprises in shaping the spatial structure of national economy in the course of systemic transformation ${ }^{1}$.

The systemic change of 1989-1990 brought about basic alteration of legal and organizational framework for the operation of economic entities (Węcławowicz, 1996; Kołodko, 2000; Gorzelak, 1999). When subjected earlier to political decision making (except for small privately-owned units), economic enterprises have become independent market actors. The institutional change involved initially a far going liberalization of conditions for starting and expanding business activity, followed by the opening of capital market to foreign capital (Pinto et al., 1993). These changes were largely completed by the time of Poland's entry to the European Union on May 1st 2004, the date that is often assumed as marking the final phase of post-socialist transition in EastCentral Europe (Kornai, 2006). Foreign direct investments played a particular role in the economic adjustment process by both diminishing the structural gap in industry and bringing the output into the global circuit (Domański, 2000; Rachwał, 2015). Especially, the inflow of vertical FDl's (Shatz

\footnotetext{
1 Total revenue of the ten largest enterprises almost equaled Poland's national budget in 2004 (Śleszyński, 2014).
} 
\& Venables, 2000; Phelps, 2008), those searching for low-cost inputs was of critical importance in re-directing Poland's foreign trade routes during the 1990's. This did not imply a scarcity of horizontal investments oriented at serving the local market, as evidenced by the fact that by the late 1990s foreign entrants were accounting for almost 80 percent of the turnover of major firms in the domain of retail trade (Wrigley, 2000). Altogether, international capital flows and the evolving pattern of inter- and intra-firm linkages were among important aspects of the unfolding economic, social, as well as spatial change.

With regard to spatial effects of systemic transformation in East-Central Europe, urban change in the region was expected to follow, with some time lag the general metropolization path (Enyedi, 1994). More specifically, the growing role of capital cities and other major urban centres (Hall, 1993), together with the declining functions of numerous medium-sized and small towns (Musil, 1993) were among the anticipated developments. When considering chances of individual cities to gain investment capital and other resources in international inter-urban competition, Elizabeth Lichtenberger predicted that:

"While the globalization of the economy is creating competition (...). for the expanding quaternary sector (....) only the primate cities will participate actively in the cooperation with, and competition between the eurometropolises and become centres for international economic and technological development. Only the primate cities will profit from the transfer policies of the international financial markets" (Lichtenberger, 1994: 29).

The latter view did not appear to match the urbanization pattern of Poland. Firstly, against other capital cities of post-socialist countries of East-Central Europe Warsaw was featuring a low primacy level in terms of population size; it was also sharing with other major cities some important functions of national range(Dziewoński, 1975). Secondly, the geopolitical change of 1989-1990 was clearly offering a competitive edge to those among the second-largest urban centres that were situated in western regions of Poland (Domański, 1994, 1999).

In this context, the research question addressed in the present paper is, whether the systemic transformation which started in 1989 has brought about spatial decentralization, or otherwise, has contributed to centralization of economic linkages, the latter identified in terms of capital ties among firms as shareholders of large enterprises. The following, alternative development paths could be initially discernible:

- When adapting to the rules of open market economy, spatial structure of economic control functions evolves towards a decentralized hierarchical pattern, in accordance with the polycentric structure of Poland's urban system. The capital city's leadership position in this domain is challenged by the growing role of major regional centres (including Poznań and Wrocław) which are more conveniently situated vis-à-vis, and linked via transportation infrastructure with West European economic core areas.

- Spatial structure of economic control functions assumes a centralized (polar) hierarchical pattern, with Warsaw as the main node, thus reflecting the inertia of the earlier pattern which prevailed under the "centrally planned" economy.

- Economic globalization, together with the metropolization process lead towards the formation of a network-like pattern of economic and social linkages among interdependent, large urban centres, the capital city being one among these.

\section{Data sources and research approach}

The network of inter-firm capital ownership relations is difficult to untangle since the web of financial ties tends to assume complicated forms (Wheeler, 1988; Laulajainen, 2003; see also Boodhoo, 2009). A simple relation 
of the kind where shares in enterprise $X$ are owned by firms $Y 1, Y 2$ etc. is rarely found and if so, it typically pertains to a situation in which the total stock, or its control packet belongs to State Treasury, or to single individuals ${ }^{2}$. In most cases the relations are compound, often forming long ownership chains (firm $A$ holds shares in firm $B$ which, in turn is dependent upon $C$ and $D$ etc.), or linkage networks (for example, firm A owns a part of the stock of $B$, but is itself owned partly by $C, D$ and $E$; the latter holding shares in $A$, while $D$ owes shares in $C$ and E). Still, while characterized by complicated morphology, capital ownership relations are at the same time of fundamental nature and even their partial disentangling may offer important information on connectivity and interdependence within a spatial (in this case urban) system. A practical study approach is to introduce certain assumptions concerning comparability rules.

Basically, an inquiry into the structure of capital ownership links can be conducted along two lines, namely:

- in which firms does firm A hold shares?

- who are the shareholders of firm $A$ ?

The first approach leads to identification of a given firm's activity range, including its spatial extent, so as to map its outward ownership links (Fig. 1A). A problem that is faced here pertains to the often substantial differentiation of the dependent units in terms of size and work scope. This approach may first of all be useful in studying links of functional, organizational type, such as relations between the parent company and its affiliates, as well as between the firm and its subcontractors, suppliers, etc (Rozenblat, 2010).

The second approach which looks at nward linkages (Fig. 1B) seems more relevant when the aim is to identify the firm's capital structure and to map capital origins. Following this line it is conceivable to mark the existing links pattern, provided that data

\footnotetext{
2 Here we assume that the state, and physical persons in particular are independent subjects, although in reality they both are bound, or restricted by various preconditions.
}

are available on capital sharing among all firms within a given territorial system (here, a state), as well as on their external capital relations. Such a complete data basis can not be assembled in reality, however, since some information is legally protected in court registers which pertains to both internal and external, i.e. transnational capital linkages.

With these limitations in mind, we chose to focus our analysis on large enterprises, which account for a bulk of major capital linkages, and to by-pass the information on shares they hold in smaller firms (Fig. C). Without a substantial loss of information it allows one to focus on these ownership relations that are crucial to the firms' operations. The large firms were defined as those with annual revenues in excess of 150 million PLN (36 million Euro, approximately). There were 1242 such enterprises in Poland in 2004, and their total annual revenue amounted to 1241 billion PLN, respectively. With regard to $71 \%$ of this sum, i.e. 885 billion PLN, it was feasible to identify the location of the shareholding firms. The remaining part, i.e. the equivalent of 261 billion PLN, which accounted for non-identified entities, including physical persons (both large single owners and firms' employees) was by-passed in the analysis. Still, the data used cover more than one half (54\%) of the total revenue value of the enterprise sector in Poland as of 2004.

At this point it is necessary to comment on selecting annual revenue value, rather than the founding capital value, as the explanatory variable in the study of interfirm ownership relations, in spite of the fact that it is the latter that defines the firm's shareholding structure. Such a nominal value is namely often irrespectively low in relation to the scale of firms' operations, and it is the revenue volume (annual value of sales) that better reflects its real size. $^{3}$

\footnotetext{
3 The case of Ostrowiec Steel Mill (1.5 billion PLN in 2004) can serve as an illustration of the existing disparities. The firm belongs to Celsa Poland (located in the town of Ostrowiec Świętokrzyski) which is

${ }^{a} n$ affiliate of a Spanish holding. At the time of purchase, the founding capital value amounted
} 
A

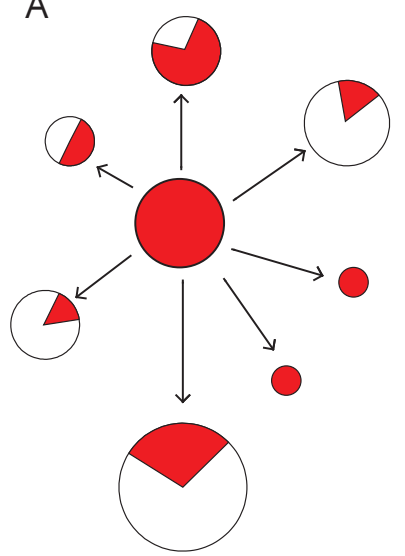

B

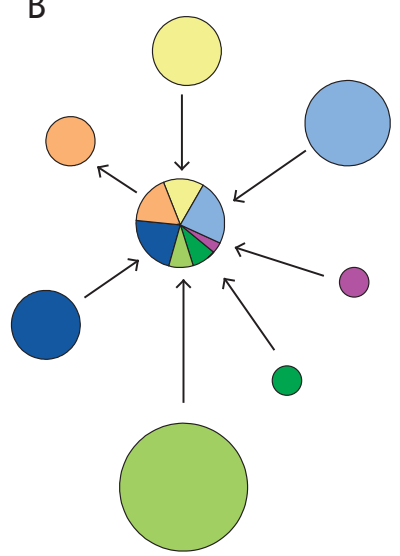

C

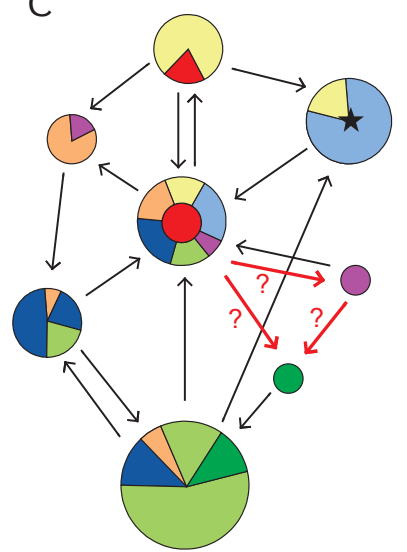

Figure 1. Approach to the measurement of inter-firm capital linkages. $A$ - the shares held by firm $X$ in other firms; $B$ - the shares of firms $Y, Z \ldots$ in firm $X ; C$ - inter-firm linkages

The spatial pattern of inter-firm capital relations, together with the location of economic control functions were analyzed by referring to hierarchical structure of the national settlement system which is based on administrative rank of individual places, but at the same time accounting for their population size. Whereas the former criterion mirrors inter-city relations concerning political status and public institutions, the latter stands as a proxy for socioeconomic characteristics. As phrased by Denise Pumain, who followed a broader discussion by Reiner and Parr (1980):

"Population size is a correlate for many quantitative descriptors, such as the number of jobs, firms and homes, but also for qualitative descriptors such as the diversity or complexity of economic activities and of urban society. It constitutes the main 'dimension' of an urban system, its most important factor of differentiation"(Pumain, 2000: 75).

Along these lines, and when accounting for urban or rural status of smaller places, seven tiers within the national settlement system were distinguished for the purpose

to PLN 50,000 which was equivalent to the value of sales of the Steel Mill's products accruing, on the average, from 17 minutes of its operation (assuming work continuity) in 2004. of the present study which more or less correspond to Philbrick's (1957) seven levels of spatial functional organization as characteristic for the metropolization age. These include:

1. the capital city of Warsaw;

2. other cities of metropolitan rank: Gdańsk, Katowice, Kraków, Łódź, Poznań, Szczecin, Wrocław ${ }^{4}$;

3. remaining voivodship centres ${ }^{5}$ : Białystok, Bydgoszcz, Gorzów Wielkopolski, Lublin, Kielce, Olsztyn, Opole, Rzeszów, Toruń, Zielona Góra;

4. subregional centres of city-poviat status. ${ }^{6}$

5. other poviat centres;

6. remaining towns;

7. rural settlements.

The data used in the analysis were obtained from the Hoppenstedt Bonnier register and supplemented by data from ranking

\footnotetext{
4 These cities (of 400,000 to 800,000 inhabitants) are identified as centres of MEGA (Metropolitan Economic Growth Areas) by ESPON (2004).

5 Voivodships (16 in number) comprise administrative units of the upper, i.e. regional level; all voivodship capitals are cities with more than 100,000 inhabitants. In two voivodships capital functions are shared by two urban centres.

6 Poviats are unit of intermediate administrative level, above the gmina (municipality) level, whereas the city-poviat status is held by the remaining larger cities, as well as some middle-sized towns, typically with above 50,000 inhabitants.
} 
lists of the 500 largest enterprises in Poland, published by Rzeczpospolita (a daily newspaper) and by weekly magazines - Gazeta Bankowa, Polityka and Nowe Życie Gospodarcze. In addition, Website pages of the individual firms as well as their annual reports were consulted.

\section{Spatial pattern of inter-firm links}

A matrix pattern of the ownership links, as expressed in aggregate revenue value of large enterprises is shown in Table 1 and Figure 2. It reveals a concentration of ownership linkages at upper levels of the settlement system. First of all, however, it documents a high share - nearly $63 \%$ of foreign ownership in the firms' total revenue volume, as well as its biggest proportion found at, and not much differentiated across the seven levels of settlement hierarchy. ${ }^{7}$ Out of the share subject to ownership control originating within Poland, a considerable majority (79\%) was accounted for by those firms, the headquarters of which were located in Warsaw. These two origins (a set of origin centres in case of foreign ownership) are jointly responsible for between 81 and $97 \%$ of the total control value over firms at each of the respective hierarchy levels (Figs. 3 and 4).

If only those links are examined, in case of which both the origin and destination points are contained within Poland's borders, then Warsaw emerges as the single node (Fig. 3). This pattern obviously reflects the concentration of firms' headquarters in the capital city ${ }^{8}$. Still, Warsaw's share in the total value of ownership links is bigger than the corresponding share in the number of firms' head offices, as the city is home to some of the largest domestic enterprises. Out of the total number of 284 links (vectors) originating from Warsaw, those of the biggest value were destined for Łódź, Katowice, Płock and, to a smaller extent, for Kraków and Wrocław. When compared with Warsaw, with its total value of outward links amounting to PLN 262 billion in 2004, cities at the third level in urban hierarchy were origins of ownership links of the equivalent revenue value of PLN 1-2 billion each only on the average. In fact, some middle-sized towns situated within the metropolitan area of Warsaw, such as Piaseczno and Sochaczew, were responsible for outward linkages exceeding in terms of aggregate revenue value (and hence of the importance of ownership-based

Table 1. Ownership control over firms located in Poland (2004)

\begin{tabular}{|l|r|r|r|r|r|r|r|r|}
\hline \multirow{2}{*}{$\begin{array}{c}\text { Outgoing control from areas } \\
\text { (centers) }\end{array}$} & \multicolumn{7}{|c|}{ Control coming to centers [in billion PLN] } \\
\cline { 2 - 10 } & CAP & \multicolumn{1}{|c|}{ MET } & VOI & SUB & POV & TOW & RUR & Total \\
\hline From abroad & 266.4 & 145.0 & 14.1 & 69.5 & 48.8 & 6.4 & 4.7 & 554.9 \\
From the capital (CAP) & 139.8 & 75.8 & 11.3 & 17.9 & 13.9 & 2.2 & 1.1 & 262.1 \\
From other metropolitan (MET) & 3.9 & 12.6 & 3.7 & 2.1 & 5.2 & 1.9 & & 29.4 \\
From other voivodship (VOI) & 1.5 & 0.8 & 2.6 & 1.0 & 0.7 & & & 6.5 \\
From other subregional (SUB) & 3.4 & 3.6 & 0.3 & 8.8 & 0.4 & & 0.5 & 17.1 \\
From other poviat centers (POV) & 3.5 & 1.6 & 0.7 & 0.7 & 5.5 & & 0.2 & 12.2 \\
From other towns (TOW) & 1.0 & 1.1 & $<0.1$ & & 0.3 & & 0.1 & 2.5 \\
From other rural areas (RUR) & & 0.2 & 0.1 & & & & 0.4 & 0.7 \\
\hline Total & 419.4 & 240.7 & 32.9 & 99.9 & 74.9 & 10.6 & 7.1 & 885.4 \\
\hline
\end{tabular}

7 The share of foreign ownership might have been actually higher by a few percentage points, since some firms were controlled via affiliates of foreign companies registered in Poland; cf. the case of Huta Ostrowiec, earlier referred to.

\footnotetext{
${ }^{8}$ In fact, a majority among these are located in Warsaw's downtown area.
} 


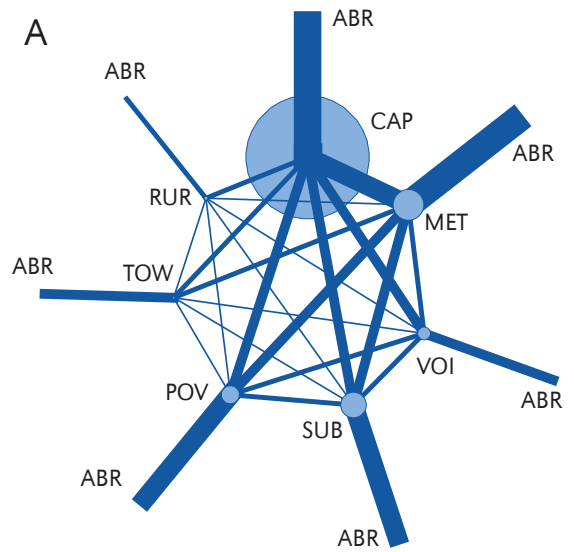

Cumulative links value

(between various categories)

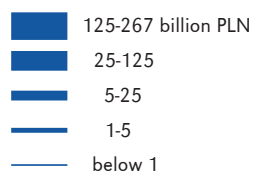

internal

(in the samecategory)

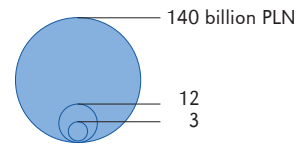

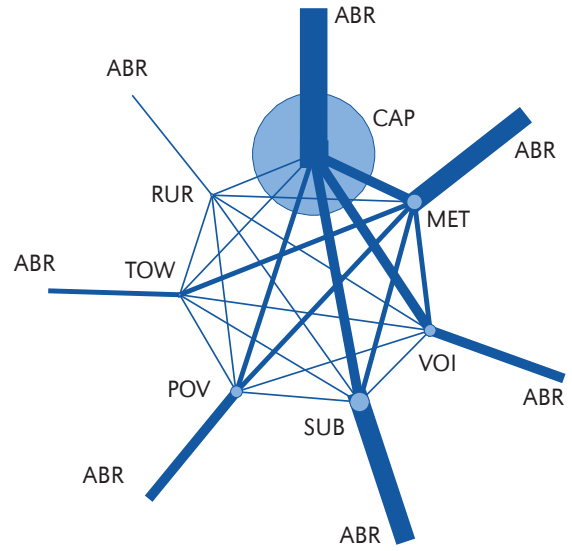

Links value per capita

external

(between various categories)

internal

(in the same category)

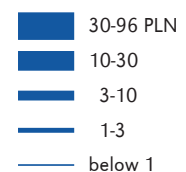

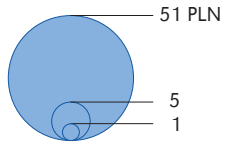

Figure 2. Ownership links of economic control centres in Poland, 2004. A - cumulative links values; $B$ - links values per capita. Abbreviations for origin and destination categories: ABR - abroad, CAP - capital city, MET - other metropolitan centres, VOI - other voivodship capitals, SUB - subregional centres of city-poviat status, POV - other poviat centres, TOW - remaining towns, RUR - rural settlements

Table 2. The ownership control from abroad by country of origin (2004)

\begin{tabular}{|l|r|r|r|r|r|r|r|r|}
\hline \multirow{2}{*}{$\begin{array}{c}\text { Outward control } \\
\text { links }\end{array}$} & \multicolumn{7}{|c|}{ Inward control at [in billion PLN] } \\
\cline { 2 - 9 } & CAP & MET & VOI & SUB & POV & TOW & RUR & Total \\
\hline Germany & 48.1 & 50.8 & 2.8 & 3.3 & 9.9 & 0.8 & 2.0 & 117.7 \\
USA & 41.3 & 14.6 & 1.9 & 40.2 & 16.9 & 0.6 & 0.3 & 115.8 \\
Netherlands & 34.0 & 23.2 & 2.3 & 8.1 & 6.9 & 1.2 & 0.0 & 75.7 \\
France & 48.9 & 9.0 & 4.6 & 2.8 & 1.7 & 0.8 & 0.3 & 67.9 \\
United Kingdom & 14.9 & 21.3 & 0.2 & 0.9 & 1.1 & 0.5 & 0.1 & 39.0 \\
Sweden & 13.0 & 2.2 & 0.5 & 1.7 & 1.1 & 0.4 & 0.3 & 19.2 \\
Hungary & 4.8 & 2.5 & 0.3 & 9.8 & & 0.2 & & 17.6 \\
Switzerland & 8.1 & 4.9 & 0.2 & 0.1 & 2.9 & 0.0 & 0.6 & 16.8 \\
Austria & 8.6 & 0.5 & 0.4 & 1.1 & 0.5 & 0.3 & & 11.4 \\
Denmark & 5.7 & 1.6 & & 1.5 & 0.3 & & 0.2 & 9.3 \\
South Korea & 6.1 & & & & 2.9 & & & 9.1 \\
Japan & 3.6 & 3.4 & 0.4 & & 0.2 & 0.3 & & 7.9 \\
Belgium & 4.8 & 1.4 & 0.2 & 0.1 & 0.4 & 0.5 & & 7.5 \\
Luxembourg & 4.8 & 0.5 & 0.3 & 0.1 & 0.4 & & & 6.1 \\
Cyprus & 5.0 & & & & & 0.8 & & 5.7 \\
other & 14.3 & 7.4 & & 0.2 & 0.2 & 1.3 & 0.1 & 23.6 \\
\hline Total & 266.1 & 143.3 & 13.9 & 69.8 & 45.4 & 7.7 & 3.8 & 550.1 \\
\hline
\end{tabular}

Abbreviations: see Table 1. 


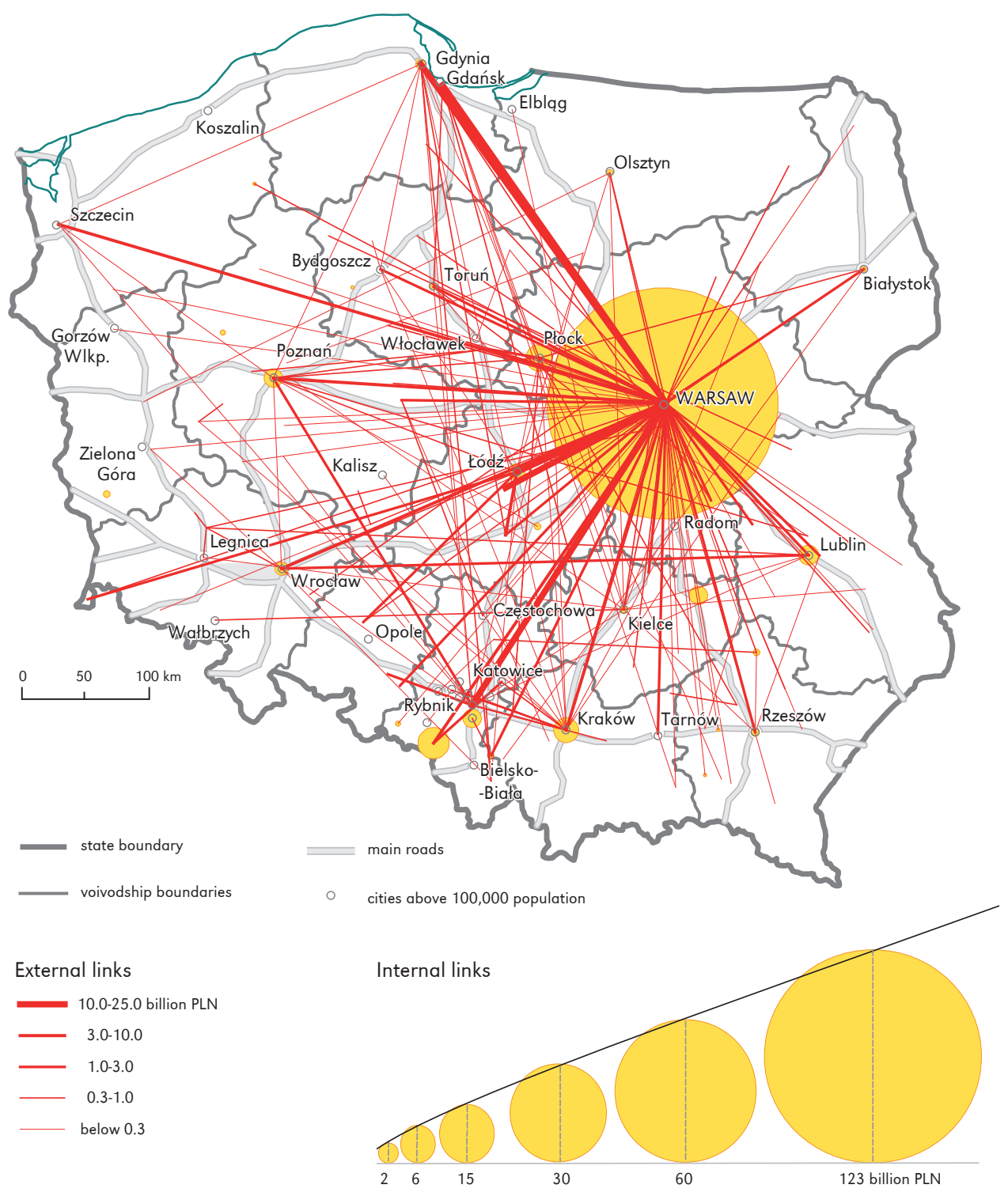

Figure 3. Spatial pattern of domestic inter-firm ownership links, 2004

control functions) those generated by some among smaller voivodship centres.

At this point one can conclude that from the standpoint of ownership related inter-firm links, the spatial organization of economic control functions in Poland is based upon two pillars - foreign direct investments in terms of capital origin, and the pivotal position of Warsaw with regard to capital distribution across space. There could be relatively few ownership links identified between urban centres situated at lower hierarchy levels, although it should be kept in mind that the analysis was restricted to the large firms. These enterprises, however, are the ones that form the main framework of spatial structure of national economy. 


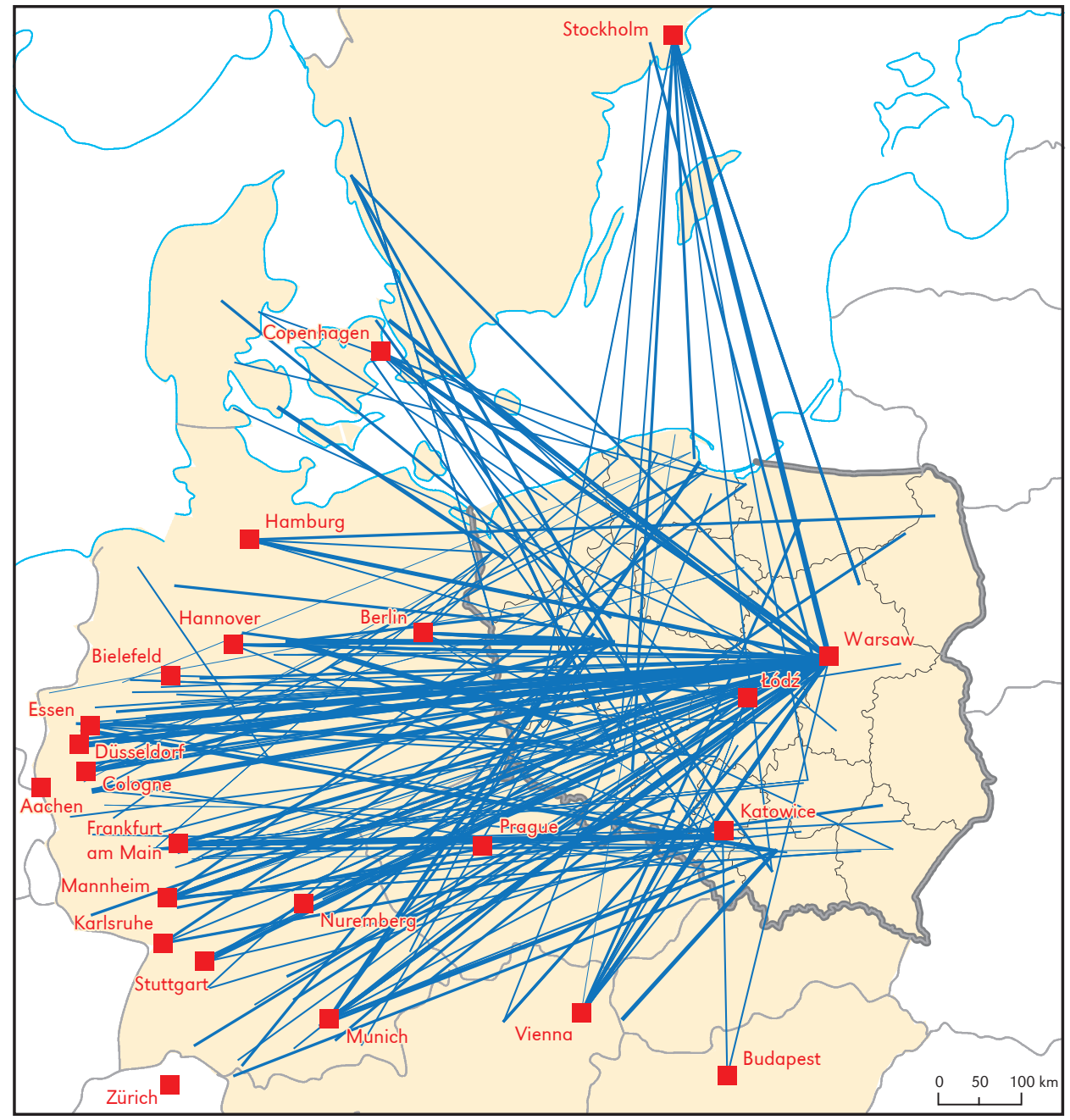

Foreign holder (ownership) links power

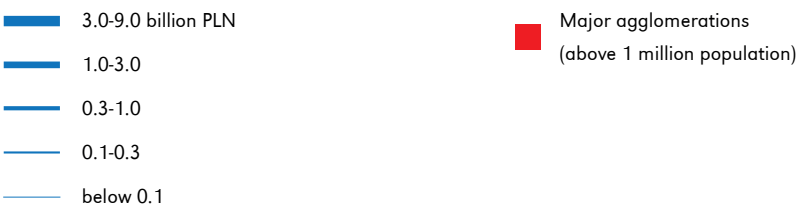

Figure 4. Ownership links from the neighboring foreign centres, 2004

Going back to foreign ownership control, it is here appropriate to show its geographical structure in some detail (Tab 2; Fig. 4). Not unexpectedly, firms registered in the Federal Republic of Germany were responsible for the largest share - 160 (almost one-fourth) out of the total number of 689 foreign inward ownership linkages. Major investments origins included also other European countries: The Netherlands (92), France (79), United Kingdom (41), Sweden (31), Switzerland (26) and Austria (25 links), respectively. Outside 
Table 3. The biggest ownership links in values and share in the total (over PLN 5 billion of revenues controlled), 2004

\begin{tabular}{|l|c|c|}
\hline \multicolumn{1}{|c|}{ Original destination } & In billion PLN & $\%$ \\
\hline Warsaw (internal) & 139.8 & 15.3 \\
Amsterdam-Warsaw & 60.3 & 7.0 \\
Paris-Warsaw & 52.9 & 6.1 \\
London-Warsaw & 36.2 & 4.2 \\
Ruhr Basin-Katowice & 31.9 & 3.7 \\
Wolfsburg-Polkowice & 14.5 & 1.7 \\
Frankfurt-Racibórz & 13.1 & 1.5 \\
Vienna-Warsaw & 12.5 & 1.5 \\
Stockholm-Zielona Góra & 12.3 & 1.4 \\
Munich-Łódź & 11.3 & 1.3 \\
New York-Warsaw & 10.6 & 1.2 \\
Turin-Bielsko-Biała & 10.1 & 1.2 \\
Łódź-Opole & 9.3 & 1.1 \\
Seoul-Warsaw & 9.1 & 1.1 \\
Zürich-Gdańsk & 8.7 & 1.0 \\
Amsterdam-Poznań & 7.3 & 0.9 \\
Tokyo-Warsaw & 7.2 & 0.8 \\
Płock-Krakow & 7.1 & 0.8 \\
Copenhagen-Warsaw & 6.8 & 0.8 \\
Luxembourg-Opoczno & 6.1 & 0.7 \\
Brussels-Warsaw & 5.8 & 0.7 \\
Hamburg-Warsaw & 5.6 & 0.6 \\
Rotterdam-Elblag & 5.4 & 0.6 \\
\hline Total (with Warsaw) & 600.3 & 68.8 \\
\hline Total (without Warsaw) & 460.5 & 53.5 \\
\hline
\end{tabular}

Europe, firms from the United States were the biggest investors (91 ownership links), followed by those from Japan (14) and the Republic of Korea (14). As to investment destinations, it is noticeable that in terms of firms' revenue controlled, the share accruing to Warsaw varied substantially, and was exceeded in case of German and British investments by that of 'other metropolitan centres'. When measured in per capita terms, however, the respective values for Warsaw were still 2.2 and 1.6 times bigger than those for the seven secondary large cities combined.

While the foreign shareholding firms were located in urban centres of various size, they generally clustered within the European economic core area, located between the South of the United Kingdom, the East of France and the West of Germany (including the Benelux countries), with the most powerful links having their points of origin in the metropolitan areas of Amsterdam (and other centres within the Randstad area), Paris, London, and the Ruhr conurbation. (Tab. 3). When expressed in the revenue value controlled, such links all exceeded in size those radiating from Warsaw down the national urban hierarchy. This documents the depth of change that occurred between 1989 and 2004, involving a large scale privatization of state owned enterprises. Concerning the pattern of domestic links, it reflects among other factors inter-sectoral structure of the capital city's economic control functions which pertain primarily to advanced service activities that tend to reveal multi-directional outward linkages.

\section{Discussion: main findings with interpretation}

The first question to be addressed is whether, or to what extent can the portrait of ownership-based control links for the year 2004 be regarded as representative of the pattern of functional relations in the national settlement system at an advanced stage of the post-socialist transition. The second question concerns the adequacy of choosing the set of large enterprises, defined on the basis of gross annual revenue value, as a means to illustrate the structure of the settlement system's inner and outer ownership links, here considered as a dimension of inter-urban connectivity and interdependence.

As to the former issue, one should point out that by the year 2004 the process of privatization of state-owned enterprises (in which foreign capital played a major part) was by and large completed?. This allows us to trace indirectly the impact of these foreign investments upon the spatial pattern of control functions which had rather closely mirrored

\footnotetext{
9 Its main phase took place from 1990 to 1995 , when more than 500 enterprises were subject to privatization annually (Rachwał, 2015).
} 
administrative urban hierarchy before $1989^{10}$. With regard to the role of large organizations (the large enterprises including) in shaping the structure of urban systems, it is here relevant to refer to the classical work by Allan Pred (1975: 115), according to whom:

"Insofar as these organizations dominate the economy they are the most important generators of goods, services, information and capital. In other words ... (they are) the major source of intermetropolitan and interurban interdependencies. "

Such a perspective is echoed in recent studies which point to the impact of large enterprises upon numerous aspects of urban development, including the local economy, urban space and social life (Csomos \& Derudder, 2014). Among these, the multiplier effects which are expressed in attracting, as well as sti,mulating the growth of small and medium-sized firms are emphasized (Śleszyński, 2002). As concluded by Christian Zeller (2010: 2867):

"By establishing networks, large firms considerably shape and interconnect the development dynamics in the regions in which they have strategic assets".

Having noted this, and at the same time acknowledging all limitations that stem from a partial character of the data used, one can attempt to formulate some generalizations, as well as some interpretations pertaining to individual levels of urban hierarchy. In the linkage pattern that emerged by the year 2004, at an advanced stage of systemic transformation, it is the capital city that functions as the main hub, or the intermediary by accumulating ownership links arriving from abroad and exercising economic control (of equivalent total revenue value)

\footnotetext{
${ }^{10}$ Actually, the inflow of foreign capital recorded a sharp increase following Poland's EU accession in 2004 (with peaks in 2007 and 2011), but became largely reoriented towards green field (and party brown field) investments.
}

at the domestic level, first of all with respect to major regional cities of metropolitan rank, and then to a number of smaller urban centres at intermediate and lower hierarchy levels. Whereas several among the large cities, especially Kraków, Poznań, Katowice, Wrocław and Gdańsk comprise important destinations for foreign capital investments, their role as second-order centres of control functions is more limited; they are also only moderately interconnected by mutual firms' ownership links. At the same time, with the balance of domestic ownership links being overwhelmingly positive for the capital city (these account for nearly 80 percent of the value of all links combined), concerning total flows the corresponding value is found negative for all the hierarchical categories of urban and rural places identified.

To summarize, as of 2004 the map of inter-firm ownership linkages was dominated by inward links from abroad, with a radial pattern of domestic outward links extending from the capital city. Regarding the latter type, a hierarchical linkage structure was prevailing at upper levels of the urban system, while giving way to a rather irregular distribution at its lower tiers. ${ }^{11}$ At the same time, when seen from the national level, the linkage system was in a disequilibrium as a consequence of a strong ascendancy of the inward over the outward links, and hence of low internalization level of ownership control functions. As our data indicate, foreign ownership control accounted for more than half of the large firms' aggregate revenue volume at each level in the settlement system. This share was actually increasing when moving down the urban hierarchy. One can therefore speak of economic dependence, as manifested by foreign ownership control in the sector of large enterprises. Such a relation, which may be interpreted by referring to the concept of uneven or polarized development (Myrdal, 1957; Hirschman, 1958) is frequently

\footnotetext{
11 Low inter-connectivity of large urban centres, except for radial-type links extending from Warsaw is corroborated by other data, including those on patterns of business travel (Komornicki \& Siłka, 2011).
} 
depicted in the form of the core-periphery model (Friedmann, 1967), and applied at various scale levels. It may be placed in a temporal framework which, as in case of evolving relations that occur in national urban systems entails phases of agglomeration and dispersal, leading (or not) to polarization reversal (Richardson, 1980). It may also be applicable in a policy-oriented debate concerning functional polycentricity of a megacity region by focusing on flows, such as organizational and cooperative links between firms in advanced producer services sector (Pain, 2008).12

The core-periphery concept is based upon the assumption concerning substantial differences existing between two areas (such as regions), one of which, i.e. the core featuring a markedly higher level of socioeconomic development. This ascendancy, when manifested in the ownership and control over the flows of goods, capital and information involves (or leads to) a dominance-type relation vis-à-vis the periphery. Since the relations of power and subordination are at the centre of the model, it constitutes a particularly suitable tool when questions of shareholdingbased economic control are the topic of study. In our analysis we refer to a two-level coreperiphery model, by accounting for a special position of Warsaw as subdominant core (Korcelli-Olejniczak, 2004). In this context, spatial relations observed can be generalized into the following pattern:

1. The international level

a) The main ownership-based control functions within the sector of large enterprises in Poland are performed from countries in Western Europe and, to a lesser degree, North America.

b) These functions are concentrated in several metropolitan cities, including: Amsterdam, Paris, London, Frankfurt

\footnotetext{
12 In the context of post-socialist transition the coreperiphery concept has also been made use of in studies on interregional socioeconomic disparities, as well as on regionalization schemes - divisions of national territory into economically growing and lagging regions (Rykiel, 1995; Domański, 2004).
}

and New York, which are at the same time the focal points for economic control in the respective countries and world regions.

c) In Poland it is the capital city that holds the pivotal role of entryport and intermediary in the accumulation of foreign investments and the distribution of ownership ties over the national space.

2. The national level

a) The capital city performs the role of subdominant core, while maintaining internal dominance across the national territory, i.e. the settlement system.

b) Othercities of metropolitan rank, including Gdańsk-Gdynia, Kraków, Poznań, Wrocław and Katowice (the Upper Silesian conurbation), as well as several mediumsized towns, including: Płock, Lubin and Jastrzębie Zdrój which are locations of large, Treasury-controlled industrial enterprises fulfill the role of secondary centres of economic control.

c) The remaining urban, together with rural places occupy semi-peripheral, or peripheral position. At these, lower urban hierarchy levels the share of foreign ownership control is generally higher than in case of larger cities. This indicates a kind of discontinuity in interurban system of functional linkages at the domestic level (at least within the sector of large enterprises) which corroborates the economic dependence thesis. ${ }^{13}$

At this point, it is necessary to ask how did the pattern of spatial relations evolve and what were the main factors responsible for its form as presented above. After 1989, disintegration of the former economic

${ }^{13}$ It should be emphasized that this regularity pertains to the large enterprises only, as covered by data used in the present study. At lower settlement system's tiers it is smaller firms that typically account for the major part of local economic base. In case of small towns and rural areas the small and medium-sized firms, which are mostly locally owned frequently comprise the sole employers. A number of such firms have developed (in particular since Poland's EU accession) a strong export orientation. 
linkage system, one characteristic of the "centrally planned economy" involved not only a weakening of the previously highly centralized, hierarchical structure of political and administrative decision control, but also a disappearance of a multitude of inter-firm ties operating in the form of supply chains. Infrastructural gaps and growing inter-urban competition were also responsible for a decreasing territorial cohesion in the urban system. A new spatial pattern of economic relations was emerging in the 1990s, one reflecting the tertialization of national economy, the rise of local entrepreneurship and a new structure of resource ownership. In this process, a partial decentralization of economic control functions, away from the capital city was taking place initially, mainly within the industrial sector (Domański, 2000). Its extent, however, was rather limited owing to several factors, one of which was the role (or at least its perception) of spatial accessibility to central governmental institutions. As phrased by Rykiel (1995):

"... the changeability and illegibility of regulations (...) leads to a situation in which spatial proximity is a kind of site rent, calculated in time and cost to be borne by the entrepreneurs".

This was actually one among preconditions that prompted Lichtenberger (1994) to formulate her radical, in fact oversimplified hypothesis concerning the role of primate cities (i.e. national capitals) in the course of systemic transformation in East-Central Europe.

Other forces that worked in favor of the continuing dominance of Warsaw as center of economic control at the national level included the inertia factor and the growing role of agglomeration benefits (Rogacki, 2006; Śleszyński, 2014) in the era of accelerating metropolitan development. The latter phenomenon, which arrived in Poland together with the onset of the systemic transformation brought about, in the form of backwash effects, the outflow of human and capital resources, including specialized economic activities from numerous smaller urban places towards the large cities and metropolitan areas (Gorzelak \& Smętkowski, 2005). Due to the availability of skilled labor, technical infrastructure as well as consumer market potential, the large urban centres and their surrounding zones became also the prime destinations for foreign direct investments (Domański, 2000; Rachwał, 2015). Warsaw was one among these, but owing to the political factor, and in spite of the city's initial infrastructural deficiencies, as well as its situation within economically less developed, eastern part of Poland, it became the main beneficiary of international capital inflow.

The entry of foreign capital was a crucial external factor in the formation of the new pattern of economic relations in Poland's urban system (Domański, 2005; Taylor \& Ciechański, 2015; Szejgiec \& Komornicki, 2015). As emphasized in the present study, the takeover of ownership control over a substantial part of large firms' revenues contributed to the retaining, if not a fostering of the capital city' position as the main center of economic control at the domestic level. At the same time, Warsaw was included into the network of transnational capital linkages based upon the crucial property rights, even if its role was restricted to one of recipient, a destination for inward capital flows. As a result a polarized, predominantly hierarchical pattern of internal links of economic control was in a sense adopted into the network-based European and global economy.

Such developments pertaining to spatial organization of economic activities were in no way a unique feature of Poland during the post-1989 period. In this domain (as well as others), throughout East-Central Europe the role of capital cities was growing irrespective of their initial position within national urban systems, be it primate, or challenged by other major centres (Korcelli \& KorcelliOlejniczak, 2015). This was in fact a part of a broader trend, since in Europe in general national capitals were benefitting from the expansion of business and other higher-order 
services (Groth, 2001). ${ }^{14}$ It was translated, for both East- and West European capitals onto upward shifts of their connectivity level within the World City Network in the 2000-2004 period (Taylor \& Aranya, 2008; Pereira \& Derudder, 2010), the trend held as at least partly attributable to their political functions.

In the case of transforming economies in East-Central Europe, however, there were also specific factors at work. One of these, which has already been alluded to above and contributed to the importance of economic gateway functions of national capital cities concerned their perception as minimumrisk location for foreign inward investments in the region (Fassmann, 1997). Still another interpretation stems from looking at urban development trends in a longer term (Korcelli, 1990). Namely, whereas under statesocialist system the growth of capital cities was restrained by explicit, industrial as was well as migration-related de-concentration policies, their subsequent expansion under open market economy can be regarded as a compensatory development phase, one based on their accumulated assets, including human capital and infrastructure.

\section{Conclusions}

What our study documents is the development of centralized pattern of economic control in space, with the pivotal role of the capital city which absorbs inward firms' ownership links from abroad and distributes the control ties down the national urban hierarchy. This pattern, one that emerged in the course of the post-socialist transition is interpreted as an outcome of intervention by several, mutually superimposed and interdependent factors of internal and of external character, including investment risk aversion and a phase-shift in the process of metropolitan

\footnotetext{
14 Actually, in case of ECE capital cities the growth trend, led by the expansion of advanced business services and of the related office construction sector continued after 2004, and gave only a limited evidence of a slowdown during the global financial crisis of 2008-2009 (Smętkowski, 2015).
}

development. It seems that such a trend, however, would have been hardly possible under market-based economic relations without a substantial inflow of foreign capital. These were in fact the rules more or less common to the transforming economies in Central and Eastern Europe.

The dominant position of Warsaw at the domestic level to a large extent determines the spatial structure of economic control across the settlement system. Such a monocentric pattern implies restricted role of places at the system's remaining hierarchical levels. In terms of Philbrick's (1957) functional organization of space, in addition to its traditional leadership position, Warsaw has maintained under market economy regime (and fostered, owing to the inflow of foreign capital) the role of the main control center, the one attributed to cities of the next lower hierarchical rank - centres of metropolitan regions (Duncan et al.,1960). This should not be interpreted, however, as an overall decline of positions held by major urban centres, other than the capital city in the national settlement system. While serving as second - order centres of economic control, as well as receivers of notable business investments, these cities have at the same time succeeded in sustaining their traditional, national-wide roles based to a considerable degree on cultural and academic functions of national importance.

Nonetheless, when seen through the lens of major inter-firm ownership links, but also more generally, in terms of location of economic activity and migration streams, the settlement system assumes a polarized structure which, at lower hierarchy levels, among middle-to-large cities and mediumsized towns, but in particular in the small towns category tends to be of progressing character. There, competition for economic functions brings backwash effects which are particularly acute in case of advanced, knowledge related activities, where local demand and also factor supply, including skilled labor becomes insufficient. In effect, the hierarchical structure which can be observed within the public sector is poorly matched by spatial 
pattern of economic activity. This, when perceived from spatial policy perspective brings problems concerning the future of functional polycentricity (Burger \& Meijers, 2012) at both the national and regional level.

With regard to the place of Warsaw within a complex, international web of capital flows, the city holds a peripheral network member status, one characterized by a scarcity of outward capital investments linkages which mirrors Poland's late entry into the global economic circuit, and a latecomer position of Warsaw (Korcelli-Olejniczak, 2012) within the European urban system (Hall, 1993). Such a position contrasts with the city's relatively high connectivity level in the networks of intra-firm organizational links, as a locus of branch offices of transnational corporations operating in the domain of advanced producer services (Derudder et al., 2008). ${ }^{15}$ This discrepancy has to be attributed to different measures of inter-urban linkages applied - those referring to ownership-based power control, as opposed to the more conventional approach focusing on management-based functions performed. What it may suggest is that whereas the capability of Warsaw (its stakeholders) to exercise control at the level of international networks of capital flows remains severely limited, the city's potential role in bridging linkages, one that stems from its human resources including professional skills can become larger. Following Allen's (2010) conceptualization and phraseology, the initial functions of an entry point into national and regional markets may be gradually evolving towards those of a switching point, ones that involve some part in forging organizational connections and holding the networks together.

To the extent that they reach beyond the time frame determined by the data used, these conclusions have to be treated as preliminary. The systematic study on the evolving patterns of economic control functions

\footnotetext{
15 This position, reflecting the overall size and dynamics of Polish economy, has actually been achieved by Warsaw in the years following Poland's entry into the European Union.
}

in the urban system following the EU Eastern Enlargement, on the formation and disintegration of capital links within city networks remains an open research task.

As to general conclusions, three points deserve further brief comments. The first question concerns the way in which inter-city economic linkages are identified and measured.

In this context, the ownership links are direct in a sense that while indicating firms' activities location, they also provide a measure of the volume of actual flows among cities and of the latter's' connectivity within city networks. Also, as pointed out by Rozenblat (2010), since the ownership-based control confers decision power, such links heavily influence the overall strategy of firms. Hence, they are important channels for transmission of information, as well as for other forms of inter-city interaction, presumably related to the value and profitability of capital assets held. The second point is, that at an international level the firms' ownership links offer one of diagnostic indicators of economic inequality and economic dependence, the representation of which, as shown by Derudder et al.(2010) is a recurrent issue in the studies on global city networks. Here, we address this question while making reference to J. Friedmann's core-periphery concept. Finally, the superimposition of the pattern of inter-city capital flows, those of a long (transnational) and a short (domestic) range upon the national settlement system's structure explains the sources of Warsaw's functional change as being an effect of its integration into the world city network with the parallel retention of its economic control over the nationalwide hinterland (Taylor et al., 2010). It also shows how power relations based upon spatial administrative system may diverge from those concerning the functions of economic control at intermediate and lower levels of national urban hierarchy.

As the paper is based on data pertaining to the period 1989-2004, i.e. in (principle) before Poland's accession to the European Union, it is worth considering possible scenarios for the development of the structure 
of ownership relations regarding the post2004 period. As the database for the latter was not available at the time when the paper was being written, conclusions on the subject are based on indirect observations. According to these, in view of the unfinished restructuring and privatization of the economy in 2004, a further influx of capital and dependence of entities on foreign countries should have been expected. However, there were many indications that this wouldn't have been the case, as some large domestic companies, such as PKN Orlen, had become very strong after 2004, while supporting the internal linkages (Śleszyński, 2015; Dorocki et al., 2019). On the other hand, some sources point to an outflow of capital from countries such as Poland to so-called tax havens (GarciaBernardo et al. 2017), which would most probably have involved the relocation of the headquarters of parent companies abroad, and/or a relocation of such headquarters to countries characterized by fiscal liberalism. These analyses presented indicate that the situation regarding the impact of the strength and direction of control functions in Poland is ambiguous and requires further research.

\section{Editors' note:}

Unless otherwise stated, the sources of tables and figures are the authors', on the basis of their own research.

\section{References}

Allen, J. (2010). Powerful city networks: More than connections, less than dominance and control. Urban Studies, 47(13), 2895-2911. https://doi.org/10.1177/0042098010377364

Beaverstock, J.V., Smith, R.G., Taylor, P.J. (2000). Globalization and world cities: Some measurement methodologies. Applied Geography, 20(1), 43-63. https://doi.org/10.1016/S0143-6228(99)00016-8

Berry, B.J.L. (1973). Growth centers in the American urban system. Cambridge, Mass.: Ballinger.

Bourne, L.S., Sinclair, R., Dziewoński, K. (Eds). (1984). Urbanization and Settlement Systems. International Perspectives. Oxford: Oxford University Press.

Boodhoo, R. (2009). Capital structure and ownership structure: A review of literature. The Journal of Online Education. January 2009. 1-8.

Borchert, J.R. (1978). Major control points in American economic geography. Annals of the Association of American Geographers, 68(2), 214-232. https://doi.org/10.1111/j.1467-8306.1978.tb01192.x

Burger, M., Meijers, E. (2012). Form follows function? Linking morphological and functional polycentricity. Urban Studies, 49(5), 1127-1149. https://doi.org/10.1177/0042098011407095

Castells, M. (2000). The Rise of the Network Society. Second edition. Oxford: Blackwell.

Castells, M. (2010). Globalisation, networking, urbanization: Reflections on the spatial dynamics of the information age. Urban Studies, 47(13), 2737-2745. https://doi.org/10.1177/0042098010377365

Cohen, R.B. (1981). The new international division of labor, multinational corporations and urban hierarchy. In M. Dear, A.J. Scott (Eds.): Urbanization and urban planning in capitalist society (pp. 287-315). New York: Methuen.

Csomos, G., Derudder, B. (2014). European cities as command and control centres, 2006-11. European Urban and Regional Studies, 21(3), 345-352. https://doi.org/10.1177/0969776412453149

Derudder, B. (2006). On conceptual confusion in empirical analyses of a transnational urban network. Urban Studies, 43(11), 2027-2046. https://doi.org/10.1080/00420980600897842

Derudder, B., Taylor, P.J., Ni P., De Vos, A., Hoyler, M., Hanssens, H., Bassens, D., Huang J., Witlox, F., Shen W., Yang X. (2010). Pathways of change: Shifting connectiveness in the World City Network, 2000-2008. Urban Studies, 47(9), 1861-1877. https://doi.org/10.1177/0042098010372682 
Derudder, B., Timberlake, M., Witlox, F. (2010). Introduction: Mapping changes in urban systems. Urban Studies, 47(9), 1835-1841. https://doi.org/10.1177/0042098010373504

Derudder, B., Witlox, F. (2005). An appraisal of the use of airline data in assessments of the world city network: A research note on data. Urban Studies, 42(13), 2371-2388. https://doi.org/10.1080/00420980500379503

Dicken, P. (1976). The multiplant business enterprise and geographical space: Some issues in the study of external control and regional development. Regional Studies, 10(4), 401-412.

Dicken, P. (2000). Places and flows: Situating international investment. In G.L. Clark, M.F. Feldmann, M.S. Gertler (Eds.): The Oxford Handbook of Economic Geography (pp. 275-291). Oxford - New York: Oxford University Press.

Domański, B. (2000). Types of investment and locational preferences of European, American and Asian manufacturing companies in Poland. In J. Parysek, T. Stryjakiewicz (Eds.): Polish Economy in Transition: Spatial Perspectives (pp. 29-39). Poznań: Adam Mickiewicz University.

Domański, B. (2004). Moral problems of Eastern wilderness: European core and Periphery. In R. Lee, D.M. Smith (Eds.), Geographies and moralities (pp. 47-61). London: Blackwell. https://doi.org/10.1002/9780470753057.ch4

Domański, B. (2005). Transnational corporations and the postsocialist economy: Learning the ropes and forging new relationships in contemporary Poland. In C. Alvstam, E. Shamp (Eds.), Linking Industries Around the World: Processes of Global Networking (pp. 147-172). Aldershot: Ashgate. https://doi.org/10.4324/9781351153928-10

Domański, R. (Ed.) (1989). The Changing Map of Europe. The Trajectory Berlin-Poznań-Warsaw. Warszawa: Rewasz.

Domański, R. (1994). Spatial organization in the process of transition from a centrally planned to a market economy. Geographia Polonica, 63(1), 5-12.

Dorocki, S., Raźniak, P., Winiarczyk-Raźniak, A. (2019). Changes in the command and control potential of European cities in 2006-2016. Geographia Polonica, 92(3), 275-288. https://doi.org/10.7163/10.7163/GPol.0149

Duncan, O.D., Scott, W.R., Lieberson, B., Duncan, B., Winsborough, H.H. (1960). Metropolis and Region. Baltimore: The Johns Hopkins University Press.

Dziewoński, K. (1975). The place of urban agglomerations in the settlement system of Poland. Geographia Polonica, 30, 9-20.

Enyedi, G. (1994). Der Wandel postsocialisticher Staedte. Mitteilungen der Oesterreichschen Geogaphischen Gesellschft, Jg., 136, 53-70.

ESPON 1.1.1. (2004): The role, specific situation and potentials of urban areas as nodes in a polycentric development. Final Report, Luxembourg: European Communities.

Fassmann, H. (Ed.) (1997). Die Rueckkehr der Regionen. Beitraege zur Regionalen Transformation Ostmetteleuropas. Wien: Verlag der Oesterreichischen Akademie der Wissenschaften.

Friedmann, J. (1967). A general theory of polarized development. Santiago: Ford Foundation, Urban and Regional Development Advisory Program in Chile, Santo Domingo.

Garcia-Bernardo, J., Fichtner, J., Takes, F.W., Heemskerk, E.M. (2019). Uncovering offshore financial centers: Conduits and sinks in the Global Corporate Ownership Network. Scientific Reports, 7, 6246. https://doi.org/10.1038/s41598-017-06322-9

Gorzelak, G. (1999). The Regional Dimension of Transformation in Central Europe. London: Routledge.

Gorzelak, G., Smętkowski, M. (2005). Metropolia i jej region w gospodarce informacyjnej. Warszawa: Wydawnictwo Naukowe Scholar.

Groth, N.B. (Ed.) (2001). Cities and networking: The Baltic Sea Region. Hornsholm: Danish Centre for Forest, Landscape and Planning.

Hall, P. (1990). Europe after 1992. Urban Challenges. Statens offentliga utredningar 1990, 33, 179-185. 
Hall, P. (1993). Forces shaping urban Europe. Urban Studies, 30(6), 883-898. https://doi.org/10.1080/00420989320080831

Hirschman, A.O. (1958). The Strategy of Economic Development. New Haven: Yale University Press.

Kołodko, G. (2000). From shock to therapy: The political economy of post-socialist transformation. Oxford: Oxford University Press.

Komornicki, T., Siłka, P. (Eds.). (2011). Functional linkages between Polish Metropolises. Warsaw: Committee on Spatial Economy and Regional Planning, Polish Academy of Sciences.

Korcelli, P. (1990). Eastern-central Europe. Urban Challenges. Statens offentliga utredningar 1990, 33, 159-177.

Korcelli-Olejniczak, E. (2004). Funkcje metropolitalne Warszawy i Berlina w latach 1990-2002. Wspótzależność pozycji w systemie miast Europy Środkowej. Warszawa: Instytut Geografii i Przestrzennego Zagospodarowania PAN.

Korcelli-Olejniczak, E. (2012). Marked by dynamics: Berlin and Warsaw in the process of functional change. In B. Derudder, M. Hoyler, R. Taylor, F. Witlox, (Eds.), International Handbook of Globalization and World Cities (pp. 517-529). Cheltenham: Edward Elgar.

Korcelli, P., Korcelli-Olejniczak, E. (2015). Metropolitan transition in East-Central Europe. Mitteilungen der Oesterreichischen Geographischen Gesellschaft, 157 Jg., 29-49.

Kornai, J. (2006). The great transformation of Central Eastern Europe. Economics of Transition, 14(2), 207-244.

Laulajainen, R. (2003). Financial geography. A banker's view. London: Routledge. https://doi.org/10.4324/9780203987346

Lichtenberger, E. (1994). Das metropolitane Zeitalter in Europa in West und Ost, Mitteilungen der Oesterreichischen Geographischen Gesellschaft, 136 Jg., 8-36.

Matthiessen, Ch.W., Schwarz, A.W., Find, S. (2010). World cities of scientific knowledge: Systems, networks and potential dynamics. An analysis based on bibliometric indicators. Urban Studies, 47(9), 1861-1897.

Musil, J. (1993). Changing urban systems in post-communist societies in Central Europe: Analysis and prediction. Urban Studies, 30(6), 889-905. https://doi.org/10.1080/00420989320080841

Myrdal, G. (1957). Economic theory and under-developed regions. London: Gerald Duckworth.

Pain, K. (2008). Examining 'core-periphery' relationships in a global city region: The case of London and South East England. Regional Studies, 42(8), 1161-1172. https://doi.org/10.1080/00343400701808857

Pereira, R.A.O., Derudder, B. (2010). Determinants of dynamics in the world city network, 2000-2004. Urban Studies, 47(9), 1949-1967. https://doi.org/10.1177/0042098010372678

Pflieger, G., Rozenblat, C. (2010). Introduction. Urban networks and urban theory: The city as a connector of multiple networks. Urban Studies, 47(13), 2723-2735.

https://doi.org/10.1177/0042098010377368

Phelps, N.A. (2008). Cluster or capture? Manufacturing foreign direct investments, external economies and agglomeration. Regional Studies, 42(4), 457-473. https://doi.org/10.1080/00343400701543256

Philbrick, A.K. (1957). Areal functional organization in regional geography. Papers and Proceedings of the Regional Science Association, 3, 87-98. https://doi.org/10.1111/j.1435-5597.1957.tb01589.x

Pinto, B., Belka, M., Krajewski, S., Shleifer, A. (1993). Transforming state enterprises in Poland: Evidence on adjustment of manufacturing firms. Brookings Papers on Economic Activity, 1, 213-270. https://doi.org/10.2307/2534605

Pred, A. (1975). On the spatial structure of organizations and the complexity of inter-metropolitan interdependence. Papers, the Regional Science Association, 35, 115-142. https://doi.org/10.1007/BF01947472

Pumain, D. (2000). Settlement systems in the evolution. Geografiska Annaler, 82(2), 73-87. https://doi.org/10.1111/j.0435-3684.2000.00075.x 
Rachwał, T. (2015). Structural changes in Polish industry after 1989. Geographia Polonica, 88(4), 575-605. https://doi.org/10.7163/gpol.0035

Reiner, T.A., Parr, J.B. (1980). A note on the dimensions of national settlement pattern. Urban Studies, 17(2), 223-230. https://doi.org/10.1080/00420988020080381

Richardson, H.W. (1980). Polarization reversal in developing countries. Papers of the Regional Science Association, 45, 67-85. https://doi.org/10.1007/BF01934655

Rogacki, H. (1996). Large industrial enterprises in Poland: Changes in the regional pattern. Quaestiones Geographicae, 25, 53-59.

Rozenblat, C. (2010). Opening the black box of agglomeration economies for measuring cities' competitiveness through international firm networks. Urban Studies, 47(13), 2841-2865. https://doi.org/10.1177/0042098010377369

Rozenblat, C., Cicille, P. (2003). Die Staedte Europas. Ein vergleichende Analyse. Forschungen, Heft 115, Bonn: Bundesamt fuer Bauwesen und Raumordnung.

Rozenblat, C., Pumain, D. (1993). The location of multinational firms in the European urban system. Urban Studies, 30(10), 1691-1709. https://doi.org/10.1080/00420989320081671

Rykiel, Z. (1995). Polish core and periphery under economic transformation. Geographia Polonica, 66, 111-124.

Shatz, H.J., Vanables, A.J. (2000). The geography of international investment. In G.L. Clark, M.P. Feldman, M.S. Gertler (Eds.), The Oxford Handbook of Economic Geography (pp. 125-145). Oxford - New York: Oxford University Press.

Smętkowski, M. (2015). The impact of the economic crisis on the metropolisation process in the capital cities of CEE countries. Studia Regionalne i Lokalne, 2(60), 32-52.

Szejgiec, B., Komornicki, T. (2015). Spatial diffentiation of Polish export linkages. Geographia Polonica, 88(1), 173-178. https://doi.org/10.7163/GPol.0011

Śleszyński, P. (2002). Struktura i rozmieszczenie ośrodków zarządzania w polskiej gospodarce w 2000 r. Przeglad Geograficzny, 65(2), 199-228.

Śleszynski, P. (2014). Headquarters of large enterprises in the spatial structure of major Polish cities. Prace Komisji Geografii Przemysłu PTG, 25, 178-193. https://doi.org/10.24917/20801653.25.10

Śleszyński, P. (2015). Economic control functions in Poland in 2013. Geographia Polonica, 88(4), 701-708. http://dx.doi.org/10.7163/GPol.0041

Taylor, P.J. (2001). Specification of the World City Network. Geographical Analysis, 33(2), 181-194. https://doi.org/10.1111/j.1538-4632.2001.tb00443.x

Taylor, P.J. (2004). World city network: A global urban analysis. London: Routledge.

Taylor, P.J. (2009). Urban economics in thrall to Christaller: A misguided search for city hierarchies in external urban relations. Environment and Planning A, 41(1), 2550-2555. https://doi.org/10.1068/a42235

Taylor, P.J., Aranya, R. (2008). A global 'urban roller coaster'? Connectivity changes in the world city network, 2000-2004. Regional Studies, 42(1), 1-16. https://doi.org/10.1080/00343400601145202

Taylor, P.J., Hoyler, M., Verbruggen, R. (2010). External urban relational process: Introducing central flow theory to complement central place theory. Urban Studies, 47(13), 2803-2818. https://doi.org/10.1177/0042098010377367

Taylor, Z., Ciechański, A. (2015). Control functions within large cities and foreign direct investment in the transport sector: Empirical evidence from Poland. Geographia Polonica, 88(4), 557-593. https://doi.org/10.7163/gpol.0034

Tonts, M., Taylor, M. (2010). Corporate location, concentration and performance: Large company headquarters in the Australian urban system. Urban Studies, 47(12), 2641-2664. https://doi.org/10.1177/0042098009359029 
Tornquist, G.E. (1984). Contact potentials in the European system. IIASA Collaborative Paper, CP-84-055, Laxenburg, Austria: International Institute for Applied Systems Analysis.

Warneryd, G. (1968). Interdependence in urban systems. Gothenburg: Region Konsult Aktiebolog.

Węcławawicz, G. (1996). Contemporary Poland. Space and society. London: University College London Press.

Wheeler, J.O. (1988). Spatial ownership links of major corporations: The Dallas and Pittsburg examples. Economic Geography, 64(1), 1-16.

Wheeler, J.O., Brown, C.L. (1985). The metropolitan corporate hierarchy in the U.S. South, 1960-1980. Economic Geography, 61(1), 66-78.

Wrigley, N. (2000). The globalization of retail capital: Themes for economic geography. In G.L. Clark, M.P. Feldman, M.S. Gertler (Eds.), The Oxford Handbook of Economic Geography (pp. 292-313). Oxford - New York.

Zeller, Ch. (2010). The pharma - biotech complex and interconnected regional innovation arenas. Urban Studies, 47(13), 2867-2894. https://doi.org/10.1177/0042098010377370 